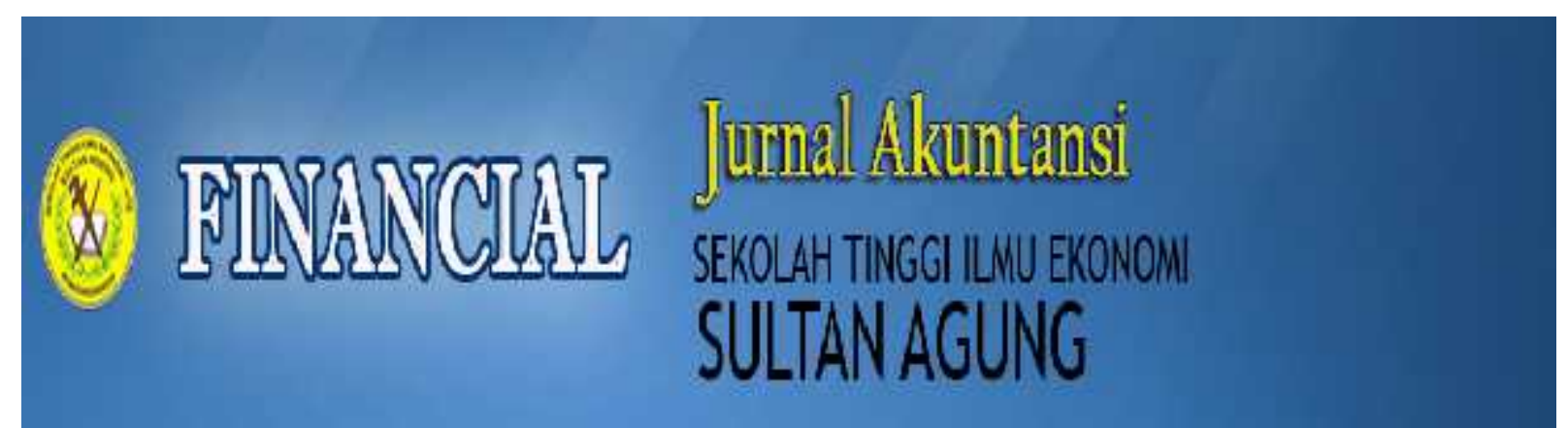

\title{
PENGARUH STRUKTUR MODAL DAN UKURAN PERUSAHAAN TERHADAP KINERJA KEUANGAN PADA PERUSAHAAN SUB SEKTOR MAKANAN DAN MINUMAN YANG TERDAFTAR DI BURSA EFEK INDONESIA
}

\author{
Oleh : \\ Pebri Yanti Karnopa Saragih \\ Sarjana Akuntansi \\ Yansen Siahaan, Elly Susanti, Supitriyani
}

Abstrak

Pebri Yanti Karnopa Saragih, pengaruh struktur modal dan ukuran perusahaan terhadap kinerja keuangan pada perusahaan sub sektor makanan dan minuman yang terdaftar di bursa efek indonesia. Di bawah bimbingan bapak dr. Yansen siahaan, se, ak., msac sebagai Ketua Pembimbing, Ibu Elly Susanti S.Kom, M.Si sebagai Anggota Pembimbing I dan Ibu Supitriyani, SE, M.Si sebagai Anggota Pembimbing II.

Tujuan dari penelitian ini adalah 1. Untuk mengetahui gambaran struktur modal, ukuran perusahaan dan kinerja keuangan pada Perusahaan Sub Sektor Makanan dan Minuman yang terdaftar di Bursa Efek Indonesia. 2. Untuk mengetahui bagaimana pengaruh struktur modal, dan ukuran perusahaan terhadap kinerja keuangan pada Perusahaan Sub Sektor Makanan dan Minuman yang terdaftar di Bursa Efek Indonesia baik secara simultan dan parsial.

Penelitian ini dilakukan dengan menggunakan metode analisis deskriptif kualitatif dan analisis deskriptif kuantitatif. Objek penelitian adalah Perusahaan Sub Sektor Makanan dan Minuman yang Terdaftar di Bursa Efek Indonesia Periode 2015-2017. Pengumpulan data dilakukan dengan metode dokumentasi. Teknik analisis yang digunakan adalah uji asumsi klasik, analisis regresi linear berganda, koefisien korelasi, koefisien determinasi dan uji hipotesis.

Hasil penelitian ini dapat disimpulkan bahwa 1. Rata-rata struktur modal cenderung menurun, rata-rata ukuran perusahaan dan kinerja keuangan cenderung meningkat. 2. Hasil pengujian dari regresi linier berganda diketahui bahwa struktur modal dan ukuran perusahaan berpengaruh negatif terhadap kinerja keuangan. 3. Hasil analisis koefisien korelasi dan korelasi determinasi dapat di ambil kesimpulan bahwa hubungan antara struktur modal dan ukuran perusahaan terhadap kinerja keuangan rendah dan cukup banyak dipengaruh oleh variabel lain yang tidak dijelaskan dalam penelitian ini. 4. Hasil uji hipotesis dapat disimpulkan bahwa struktur modal dan ukuran perusahaan berpengaruh tidak signifikan terhadap kinerja keuangan.

Hasil penelitian menyarankan sebaiknya perusahaan mempertahankan dan meningkatkan stabilitas penjualan, mengelolah struktur aset perusahaan, meningkatkan pertumbuhan perusahaan, meningkatkan laba, serta meningkatkan flesibilitas keuangan agar struktur modal perusahaan dapat optimal. Kemampuan perusahaan dalam mengelolah aset menunjukan kinerja perusahaan yang baik dan hal ini akan dapat menarik perhatian eksternal untuk ikut mendanai kegiatan perusahaan.

Kata kunci: Struktur Modal, Ukuran Perusahaan, dan Kinerja Keuangan.

\section{Abstract}

Pebri Yanti Karnopa Saragih, the Influence of Capital Structure and Company Size on financial performance in the Food and Beverage Sub-Sector Registered on the Indonesia Stock Exchange. Under the guidance of Dr. Yansen Siahaan, SE, Ak., MSAc as Advisor, Elly Susanti S.Kom, M.Si, as the First Co Advisor and Supitriyani, SE, M.Si, as the second Co Advisor.

The purpose of this study is 1. To find out the description of capital structure, company size and financial performance in the Food and Beverage Sector Company listed on the Indonesia Stock Exchange. 2. To find out how the capital structure influences, and the size of the company on the financial performance of the Food and Beverage Sector Company listed on the Indonesia Stock Exchange both simultaneously and partially.

This research was conducted using qualitative descriptive analysis methods and quantitative descriptive analysis. The object of research is the Food and Beverage Sub-Sector Company Listed on the Indonesia Stock Exchange for the 2015-2017 Period. Data collection is done by documentation method. The analysis technique used is the classical assumption test, multiple linear regression analysis, correlation coefficient, determination coefficient and hypothesis testing.

The results of this study can be summarized as follows:that 1. The average capital structure tends to decrease, the average company size and financial performance tends to increase. 2. The results of multiple linear regression tests revealed that the capital structure and firm size negatively affect financial performance. 3. The results of the analysis of the correlation coefficient and 
determination correlation can be concluded that the relationship between capital structure and the size of the company is low and much influenced by other variables that did not discribe in this study. 4. The results of testing the hypothesis can be concluded that the capital structure has no significant effect on financial performance, and the size of the company has no significant effect on financial performance.

The results show that the best is to maintain and improve sales stability, manage the structure of the company's assets, increase the company's growth, increase profits, and increase financial flexibility so that the company's capital structure can be optimized. The company's ability to manage assets shows good company performance and this will attract external attention to participate in funding the company's activities.

Keywords: Capital Structure, Company Size, and Financial Performance.

\section{PENDAHULUAN}

\subsection{Latar Belakang Masalah}

Era milinea berpengaruh terhadap perkembangan dunia bisnis di Indonesia. Hal ini dibuktikan dengan banyaknya perusahaanperusahaan yang tumbuh dan berkembang di bidang usaha yang dijalani. Hal ini menyebabkan persaingan di dunia bisnis menjadi ketat dan perusahaan dituntut untuk menjadi perusahaan yang lebih baik serta kreatif. Oleh karena itu, dapat dipastikan akan banyak perusahaan baik yang sudah ada maupun baru masuk ke Indonesia, yang melihat potensi besar untuk menumbuhkan bisnis di Indonesia.

Persaingan di industri barang konsumsi pun tidak bisa dihindari. Persaingan bukan hanya terjadi antar perusahaan tetapi juga antar negara. Meningkatnya pesaing atau competitor perusahaan barang konsumsi dari negara lain yang produknya lebih murah dengan produk yang bersaing berperan dalam menekan pertumbuhan sektor industri barang dan konsumsi di Indonesia. Dengan demikian manajemen perusahaan dinilai dari kemampuan dalam meningkatkan kinerja perusahaan.

Kinerja keuangan adalah suatu tampilan keadaan secara utuh atas perusahaan selama periode waktu tertentu dalam memanfaatkan sumber-sumber daya yang dimiliki. Salah satu indikator untuk mengukur kinerja keuangan adalah Return On Assets (ROA) yang merupakan hubungan antara laba setelah pajak dengan Aset. ROA adalah rasio yang menunjukan kemampuan perusahaan dalam menghasilkan laba atas aktiva yang digunakan. Semakin besar ROA menunjukan kinerja semakin baik, karena return semakin besar.

Perusahaan yang diteliti dalam penelitian ini adalah Perusahaan Sub Sektor Makanan dan Minuman yang Terdaftar di Bursa Efek Indonesia. Penulis memilih Perusahaan Sub Sektor Makan dan Minuman karena dianggap bahwa perusahaan ini dapat bertahan dalam keadaan krisis global dan tetap berdiri karena adanya kebutuhan sehari hari masyarakat akan makanan dan minuman. Gambaran Struktur Modal, Ukuran Perusahaan dan
Kinerja keuangan dari Perusahaan Sub Sektor Makan dan Minuman yang Terdaftar di Bursa Efek Indonesia periode 2013-2017 disajikan dalam Tabel 1.1.

Tabel 1.1

Gambaran Struktur Modal, Ukuran Perusahaan dan Kinerja Keuangan pada Perusahaan Sub Sektor Makan dan Minuman yang Terdaftar di Bursa Efek Indonesia Periode 2015-2017

\begin{tabular}{|c|c|c|c|}
\hline Tahun & $\begin{array}{c}\text { Struktur } \\
\text { Modal } \\
\text { (kali) }\end{array}$ & $\begin{array}{c}\text { Ukuran } \\
\text { Perusahan } \\
\text { (kali) }\end{array}$ & $\begin{array}{c}\text { Kinerja } \\
\text { Keuangan } \\
\text { (kali) }\end{array}$ \\
\hline 2015 & 0,344 & 28,819 & 0,109 \\
\hline 2016 & 0,317 & 28,948 & 0,138 \\
\hline 2017 & 0,225 & 29,106 & 0,128 \\
\hline $\begin{array}{c}\text { Rata- } \\
\text { rata } \\
\text { (kali) }\end{array}$ & 0,295 & 28,957 & 0,125 \\
\hline
\end{tabular}

Sumber: www.idx.co.id (Data Diolah)

Dari tabel 1.1, bahwa struktur modal proksi Long Term Debt to Equity Ratio (LTDER) pada periode 2015-2017 mengalami fluktuasi dan cenderung menurun sedangkan kinerja keuangan mengalami fluktuasi dan cenderung meningkat. Ukuran perusahaan proksi Ln(Total Aset) pada periode 2015-2017 terlihat mengalami peningkatan sedangkan kinerja keuangan mengalami fluktuasi dan cenderung menurun.

\subsection{Rumusan Masalah}

1. Bagaimana gambaran struktur modal, ukuran perusahaan dan kinerja keuangan pada Perusahaan Sub Sektor Makanan dan Minuman yang Terdaftar di Bursa Efek Indonesia.

2. Bagaimana pengaruh struktur modal, dan ukuran perusahaan terhadap kinerja keuangan pada Perusahaan Sub Sektor Makanan dan Minuman yang Terdaftar di Bursa Efek Indonesia baik secara simultan maupun parsial.

\subsection{Tujuan Penelitian}

1. Untuk mengetahui gambaran struktur modal, ukuran perusahaan dan kinerja keuangan pada Perusahaan Sub Sektor Makanan dan Minuman yang Terdaftar di Bursa Efek Indonesia.

2. Untuk mengetahui pengaruh struktur modal, dan ukuran perusahaan terhadap kinerja keuangan pada Perusahaan Sub Sektor Makanan dan Minuman yang 
Terdaftar di Bursa Efek Indonesia baik secara simultan maupun parsial.

\subsection{Metodologi Penelitian}

Penelitian ini menggunakan data sekunder dengan cara mengakses dari situs http://www.idx.co.id. Desain penelitian ini adalah penelitian kepustakaan (library research). Teknik analisis data yang digunakan adalah uji asumsi klasik, analisis deskriptif kualitatif, analisis deskriptif kuantitatif.

\section{LANDASAN TEORI}

\subsection{Akuntansi}

Akuntansi dapat dipahami sebagai sebuah bahasa bisnis dalam menyampaikan informasiinformasi keuangan kepada pihak yang membutuhkannya. Menurut Hongren dan Walter (2007:4) dalam pendapatnya menyatakan tentang akuntansi yaitu, "sistem informasi yang mengukur kegiatan bisnis, mengolah data menjadi laporan, dan mengkomunikasikan informasinya kepada para pengambil keputusan (stakeholder)". Selanjutnya menurut Rudianto (2009:4), "akuntansi adalah sebuah sistem informasi yang menghasilkan informasi keuangan kepada pihak-pihak yang berkepentingan mengenai aktivitas ekonomi dan kondisi suatu perusahaan".

Sedangkan menurut Baridwan (2004:1), "akuntansi adalah suatu kegiatan jasa yang fungsinya adalah menyediakan data kuantitatif terutama yang mempunyai sifat keuangan dari kesatuan usaha ekonomis yang dapat digunakan dalam pengambilan keputusankeputusan ekonomi dalam memilih alternatifalternatif dari suatu keadaan".

\subsection{Laporan Keuangan}

Laporan keuangan merupakan hasil akhir dari proses akuntansi yang disusun menurut prinsip-prinsip akuntansi yang berlaku umum. Proses akuntansi adalah pengumpulan data dan pengolahan data keuangan perusahaan. Dalam akuntansi didefinisikan sebagai transaksi atau peristiwa yang menjadi kegiatan ekonomi perusahaan, yang dilakukan melalui pencatatan, penggolongan dan pengikhtisaran transaksi-transaksi yang bersifat keuangan sehingga hanya informasi yang relevan dan saling berhubungan satu sama lain yang mampu memberikan gambaran keadaan keuangan dalam suatu periode yang akan disajikan dalam bentuk laporan keuangan.

Selanjutnya menurut Baridwan (2004:17), "laporan keuangan merupakan ringkasan dari suatu proses pencatatan dari transaksitransaksi keuangan yang terjadi selama tahun buku yang bersangkutan". Sedangkan oleh Munawir (2014:2) laporan keuangan yakni, " hasil dari pemrosesan akuntansi yang dapat digunakan sebagai alat dalam berkomunikasi antara data keuangan atau kegiatan suatu perusahaan dengan pihak yang berkepentingan dengan data atau kegiatan perusahaan tersebut". Sedangkan menurut Martani, dkk (2012:62), "laporan keuangan merupakan informasi bagi para penggunanya terutama pemilik perusahaan, investor, kreditur dan juga manajemen untuk mengambil keputusan-keputusan terkait perusahaan dimasa mendatang".

\subsection{Analisa Laporan Keuangan}

Analisa laporan keuangan atau disebut juga analisis laporan keuangan. Melakukan analisis terhadap laporan keuangan berarti melakukan pengukuran kinerja dan pencapaian perusahaan. Pengukuran kinerja yang dilakukan setiap periode tertentu sangat bermanfaat untuk menilai seberapa baik pencapaian perusahaan dan kemajuan yang dialami perusahaan dalam periode tertentu, serta menghasilkan informasi yang sangat bermanfaat bagi manajemen dan pemakainya untuk mengambil keputusan yang tepat agar dapat dijadikan dasar untuk mengevaluasi kinerja untuk lebih baik di periode berikutnya serta mampu menjaga nama baik dan nilai perusahaan.

Menurut Rudianto (2013:190), "analisis laporan keuangan adalah meneliti hubungan yang ada di antara unsur-unsur pada laporan keuangan dan membandingkan unsur-unsur pada laporan keuangan tahun berjalan dengan unsur-unsur yang sama tahun lalu atau angka pembandingan lain serta menjelaskan penyebab perubahan".

Sedangkan pengertian analisis laporan keuangan menurut Harahap (2008:190) didefinisikan sebagai, "pos-pos laporan keuangan yang dibagi menjadi unit informasi yang lebih kecil dan melihat kausalitas yang bersifat signifikan/penting atau yang mempunyai makna antara yang satu dengan yang lain maupun antara data kuantitatif atau data non kuantitatif dengan tujuan untuk mengetahui kondisi keuangan yang lebih dalam dan sangat penting dalam proses menghasilkan keputusan yang tepat".

Sedangkan menurut Astuti (2004:29), "analisis laporan keuangan adalah segala sesuatu yang menyangkut penggunaan informasi akuntansi untuk membuat keputusan bisnis dan investasi".

\subsection{Rasio Keuangan}

Adalah alat analisis keuangan perusahaan dalam mengukur kinerja suatu perusahaan berdasarkan perbandingan data keuangan yang terdapat pada pos laporan keuangan (neraca, laporan laba/rugi, laporan arus kas). Analisis rasio dapat digunakan untuk membimbing investor dan kreditor untuk membuat keputusan atau pertimbangan tentang pencapaian perusahaan dengan menjelaskan hubungan tertentu antara angka yang satu dengan angka yang lain dari suatu laporan keuangan. 
Menurut Munawir (2014:65), "rasio keuangan adalah dasar untuk menilai dan mengarahkan prestasi operasi perusahaan". Di samping itu, rasio keuangan disebut juga dapat dipergunakan sebagai kerangka kerja perencanaan dan pengendalian. Menurut Subramanyam dan John (2010:40), " rasio keuangan adalah analisis laporan keuangan yang paling banyak dipakai untuk mengevaluasi kinerja keuangan". Sedangkan menurut Horne dan John (2013:163), "rasio keuangan adalah alat yang menghubungkan dua buah data keuangan dengan membagi satu angka dengan yang lainnya".

\subsection{Struktur Modal}

Struktur modal (capital structure) yang berkaitan dengan pembelanjaan jangka panjang suatu perusahaan yang diukur dengan perbandingan utang jangka panjang dengan modal sendiri. Berikut menurut Sudana (2011:143), "struktur modal adalah pembelanjaan jangka panjang suatu perusahaan yang diukur dengan perbandingan utang jangka panjang dengan modal sendiri". Selanjutnya menurut Halim (2007:58), “ Struktur modal adalah perimbangan jumlah utang jangka pendek yang bersifat tetap, jangka panjang, saham preferen dan saham biasa".

Selain itu, menurut Brigham dan Joel (2011:155), "struktur modal adalah pembelanjaan jangka panjang suatu perusahaan yang diukur dengan perbandingan utang jangka panjang dengan modal sendiri". Berdasarkan penjelasan di atas dapat disimpulkan bahwa struktur modal adalah kombinasi antara utang jangka panjang dengan modal sendiri untuk pembelanjaan jangka panjang perusahaan.

\subsection{Ukuran Perusahaan}

Ukuran perusahaan memengaruhi nilai perusahaan karena semakin besar ukuran perusahaan atau skala perusahaan maka akan semakin mudah pula perusahaan memperoleh sumber pendanaan. Menurut Sawir (2004:101), "ukuran perusahaan menggambarkan ukuran besar kecilnya suatu perusahaan yang ditunjukan oleh total aset, jumlah penjualan, rata-rata total penjualan dan rata-rata total aset". Sedangkan menurut Riyanto (2009:313), "ukuran perusahaan adalah besar kecilnya perusahaan dilihat dari besarnya nilai equity, nilai penjualan dan nilai aset".

Sartono (2010:249) mengartikan, "perusahaan besar yang sudah well established akan lebih mudah memperoleh modal di pasar modal dibandingkan dengan perusahaan kecil, karena kemudahan akses tersebut berarti perusahaan besar miliki fleksibelitas yang lebih besar". Berdasarkan pengertian menurut ahli di atas, maka penulis menarik kesimpulan bahwa ukuran perusahaan adalah besar kecilnya perusahaan yang dapat dilihat dari nilai ekuitas, nilai aset, penjualan ataupun rata-rata penjualan pada beberapa tahun tertentu.

\subsection{Kinerja Keuangan}

Kinerja keuangan dalam penelitian ini adalah membahas tentang kinerja dan segi keuangan. Kinerja keuangan merupakan gambaran pencapaian dari suatu perusahaan. Kinerja keuangan dapat diperoleh dari informasi yang terjadi laporan keuangan. Selanjutnya menurut Munawir (2010:30), "kinerja keuangan merupakan satu di antara dasar penilaian mengenai kondisi keuangan perusahaan yang dilakukan berdasarkan analisa terhadap rasio keuangan perusahaan". Selain itu, menurut Fahmi (2011:2), "kinerja keuangan adalah suatu analisa yang dilakukan untuk melihat sejauh mana suatu perusahaan telah melaksanakan dengan menggunakan aturan-aturan pelaksanaan keuangan secara baik dan benar.

Sedangkan menurut Rudianto (2013:189), "kinerja keuangan merupakan hasil atau prestasi yang telah dicapai oleh manajemen perusahaan dalam menjalankan fungsinya mengelola aktivitas perusahaan secara efektif selama periode tertentu". Dari pengertian di atas Kinerja keuangan sangat dibutuhkan oleh perusahaan untuk mengetahui dan mengevaluasi sampai dimana tingkat keberhasilan perusahaan berdasarkan aktivitas keuangan yang telah dilaksanakan.

\subsection{Pengaruh Struktur Modal Dan Ukuran} Terhadap Kinerja Keuangan

Struktur modal adalah kombinasi antara utang jangka panjang dengan modal sendiri untuk pembelanjaan jangka panjang perusahaan. Sedangkan ukuran perusahaan adalah besar kecilnya perusahaan yang dapat dilihat dari nilai ekuitas, nilai aset, penjualan ataupun rata-rata penjualan pada beberapa tahun tertentu.

Struktur modal dan ukuran perusahaan merupakan faktor yang dapat mempengaruhi kinerja keuangan. Menurut penelitian Ristania (2017), "struktur modal berpengaruh signifikan terhadap kinerja perusahaan dan ukuran perusahaan berpengaruh tidak signifikan terhadap kinerja perusahaan". Dengan demikan penulis dapat menarik kesimpulan bahwa struktur modal dan ukuran perusahaan dapat mempengaruhi kinerja keuangan perusahaan, sekaligus meningkatkan kemakmuran para pemegang saham.

3. PEMBAHASAN

3.1. Analisis

3.1.1. Gambaran Struktur Modal pada Perusahaan Sub Sektor Makanan dan Minuman yang Terdaftar di Bursa Efek Indonesia Periode 2015-2017

Berikut ini di sajikan gambaran struktur modal pada Perusahaan Sub Sektor Makanan 
dan Minuman yang terdaftar di Bursa Efek Indonesia Periode 2015-2017 dalam Tabel 3.1

Tabel 3.1

Gambaran Struktur Modal pada Perusahaan Sub Sektor Makanan dan Minuman yang Terdaftar di Bursa Efek Indonesia Periode 2015-2017

\begin{tabular}{|c|c|c|c|c|c|}
\hline \\
\hline \begin{tabular}{|c|}
$\mathrm{K}$ \\
$\mathrm{o}$ \\
$\mathrm{d}$ \\
$\mathrm{e}$ \\
Emite \\
$\mathrm{n}$
\end{tabular} & Nama Perusahaan & $\begin{array}{l}2015 \\
\text { (Kali) }\end{array}$ & $\begin{array}{l}2016 \\
\text { (Kali) }\end{array}$ & $\begin{array}{l}2017 \\
\text { (Kali) }\end{array}$ & $\begin{array}{l}\text { Rata- } \\
\text { rata } \\
\\
\text { (Kali) }\end{array}$ \\
\hline \multicolumn{2}{|c|}{ CEKA PT Wilmar Cahaya Indonesia, Tbk } & 0,046 & 0,038 & & 0,045 \\
\hline \multirow{2}{*}{\multicolumn{2}{|c|}{$\begin{array}{l}\text { DLTA PT Delta Djakarta, Tbk } \\
\text { ICBP PT Indofood C CPP Sukses Makmur, }\end{array}$}} & 0,057 & 0,047 & 0,049 & 0,051 \\
\hline & & 0,255 & 0.212 & & \\
\hline \multicolumn{2}{|c|}{$\begin{array}{l}\text { ICBP Tbk } \\
\text { INDF PT Indofood Sukses Makmur, Tbk }\end{array}$} & 0,547 & 0,433 & 0,418 & 0,466 \\
\hline \multicolumn{2}{|c|}{$\begin{array}{l}\text { MLBI |PT Multi Bintang Indonesia, Tbk } \\
\text { MYORPT Mayora Indah, Tbk }\end{array}$} & 0,155 & 0,156 & 0,132 & 0,148 \\
\hline \multirow{2}{*}{\multicolumn{2}{|c|}{ ROTI PT Nippon Indosari Corporindo, Tbk }} & $0,0,944$ & 0,802 & 0,253 & \\
\hline & & 0,355 & 0,446 & 0,086 & 0,296 \\
\hline \multicolumn{2}{|c|}{$\begin{array}{l}\text { SKBMPT Sekar Bumi, , Tbk } \\
\text { SKLT PT Sekar Laut, Tbk }\end{array}$} & 0,434 & 0,347 & 0,381 & 0,387 \\
\hline \multicolumn{2}{|c|}{$\begin{array}{l}\text { SKLT PT Sekar Laut, Tbk } \\
\text { STTP PT Siantar Top, Tbk }\end{array}$} & & 0,523 & 0,432 & 0,436 \\
\hline \multicolumn{2}{|c|}{$\begin{array}{l}\text { STTP PT Siantar Top, Tbk } \\
\text { ULTJ PT Ultrajaya Milk Industry, Tbk }\end{array}$} & 0,065 & 0,045 & 0,037 & 0,049 \\
\hline \multicolumn{2}{|c|}{ Rata-rata per Tahun (Kali) } & $\frac{0,34}{4}$ & 0,317 & 0.207 & \\
\hline \multirow{2}{*}{\multicolumn{5}{|c|}{$\begin{array}{c}\text { Nilai Struktur Modal Minimum (Kali) } \\
\text { Nilai Struktur Modal Maksimum (Kali) }\end{array}$}} & $\begin{array}{l}0,037 \\
0,0,944\end{array}$ \\
\hline & $\begin{array}{c}\text { Nilai Strtuktur Modal Ma } \\
\text { Rata-rata Keseluru }\end{array}$ & & & & 0,944 \\
\hline
\end{tabular}

\section{Sumber: Data diolah}

Berdasarkan Tabel 3.1 terlihat struktur modal pada Perusahaan Sub Sektor Makanan dan Minuman yang Terdaftar di Bursa Efek Indonesia Periode 2015-2017 cenderung menurun. Hal ini disebabkan oleh jumlah hutang jangka panjang yang rendah dibandingkan total ekuitas.

3.1.2. Gambaran Ukuran Perusahaan pada

Perusahaan Sub Sektor Makanan dan Minuman yang Terdaftar di Bursa Efek Indonesia Periode 2015-2017

Berikut ini disajikan gambaran ukuran perusahaan pada perusahaan Sub Sektor Makan dan Minuman yang Terdaftar di bursa Efek Indonesia periode 2015-2017 di Tabel 3.2 Tabel 3.2

Gambaran Ukuran Perusahaan pada PerusahaanSub Sektor Makanan dan Minuman yang Terdaftar di Bursa Efek Indonesia Periode 2015-2017

\begin{tabular}{|c|c|c|c|c|c|}
\hline $\begin{array}{c}\text { Kod } \\
e \\
\text { Emiten }\end{array}$ & Nama Perusahaan & $\begin{array}{l}2015 \\
\text { (Kali) }\end{array}$ & $\begin{array}{l}2016 \\
\text { (Kali) }\end{array}$ & $\begin{array}{l}2017 \\
\text { (Kali) }\end{array}$ & 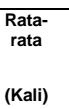 \\
\hline CEKA & PT Wilmar Cahaya Indonesia, Tbk & 28,027 & 27,986 & 27,924 & 27,890 \\
\hline DLTA & PT Delta Djakarta, Tbk & 27.669 & 27.812 & 27.924 & 29,399 \\
\hline ICBP & $\begin{array}{l}\text { PT Indofood CBP Sukses Makmur, } \\
\text { Tbk }\end{array}$ & 30,910 & 30,995 & 31,085 & 31,548 \\
\hline INDF & PT Indofood Sukses Makmur, Tbk & 32,151 & 32,040 & 32,108 & 30,279 \\
\hline MLBI & PT Multi Bintang Indonesia, Tbk & 28,373 & 28,453 & 28.551 & 29,327 \\
\hline MYOR & PT Mayora Indah, Tbk & 30,060 & 30,190 & 30,333 & 29,510 \\
\hline ROTI & $\begin{array}{l}\text { PT Nippon Indosari Corporindo, } \\
\text { Tbk }\end{array}$ & 28,627 & 28,702 & 29,148 & 28,265 \\
\hline SKBM & PT Sekar Bumi, Tbk & 27,362 & 27,633 & 28,115 & 27,335 \\
\hline SKLT & PT Sekar Laut, Tbk & 26,656 & 27,066 & 27,179 & 27,691 \\
\hline STTP & PT Siantar Top, Tbk & 28,283 & 28,480 & 28,482 & 28,749 \\
\hline ULTJ & PT Ultrajaya Milk Industry, Tbk & 28,895 & 29,075 & 29,277 & 29,020 \\
\hline & Rata-rata per Tahun (Kali) & 28,819 & 28,948 & 29,102 & 28,957 \\
\hline \multirow{2}{*}{\multicolumn{4}{|c|}{$\begin{array}{l}\text { Nilai Ukuran Perusahaan Minimum (kali) } \\
\text { Nilai Ukuran Perusahaan Maksimum (kali) }\end{array}$}} & \multicolumn{2}{|r|}{26,656} \\
\hline \multicolumn{2}{|c|}{$\begin{array}{c}\text { Nilai Ukuran Perusahaan Maksimum (kali) } \\
\text { RRata-rata keseluruhan (kali) }\end{array}$} & & & & $\begin{array}{l}\frac{23,151}{28,957} \\
2\end{array}$ \\
\hline
\end{tabular}

Sumber : Data Diolah

Berdasarkan Tabel 3.2 dapat dilihat bahwa nilai rata-rata ukuran perusahaan pada
Perusahaan Sub Sektor Makanan dan Minuman yang Terdaftar di Bursa Efek Indonesia periode 2015-2017 mengalami peningkatan. Hal ini disebabkan dari total aset yang meningkat. Oleh karena itu, perusahaan memiliki kebutuhaan dana yang besar dan salah satu alternatif pemenuhan dana yang tersedia adalah dengan pendanaan aset. Sehingga, dalam rangka pemenuhan pendanaan tersebut akan lebih meningkatkan kinerja dalam menjalankan perusahaan

3.1.3. Gambaran Kinerja Keuangan pada Perusahaan Sub Sektor Makanan dan Minuman yang Terdaftar di Bursa Efek Indonesia Periode 2015-2017

Berikut disajikan kondisi Return On Assets (ROA) pada Perusahaan Sub Sektor Makanan dan Minuman yang Terdaftar d Bursa Efek Indonesia periode 2015-2017 pada Tabel 3.3.

$$
\text { Tabel } 3.3
$$

Gambaran Kinerja Keuangan pada Perusahaan Sub Sektor Makanan dan Minuman yang Terdaftar di Bursa Efek Indonesia Periode 2015-2017

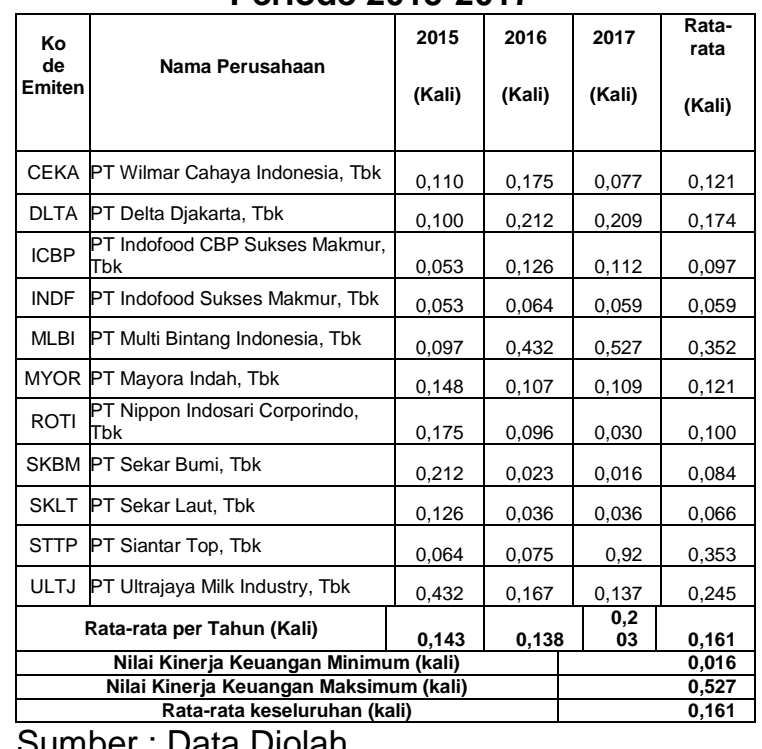
Sumber : Data Diolah

Berdasarkan Tabel 3.3 dapat dilihat bahwa rata-rata kinerja keuangan pada Perusahaan Sub Sektor Makanan dan Minuman yang Terdaftar di Bursa Efek Indonesia periode 2015-2017 berfluktuasi dan cenderung meningkat. Hal ini disebabkan karena perusahaan Sub Sektor Makanan dan Minuman mengalami peningkatan total aset perusahaan. Peningkatan kinerja keuangan menunjukan kemampuan kinerja yang baik bagi perusahaan.

\subsubsection{Analisis Deskrisptif Kuantitatif}

\section{1) Regresi Linier Berganda}

Analisis regresi linier berganda pada penelitian menggunakan SPSS versi 20 dapat terlihat pada Tabel 3.4:

Tabel 3.4

Hasil Analisis Regresi Linier Berganda \begin{tabular}{|l|l|l|}
\hline Model & Unstandardized & Standardized Coefficients \\
\hline
\end{tabular} 


\begin{tabular}{|c|c|c|c|c|}
\hline & & $B$ & Std. Error & Beta \\
\hline & (Constant) & 210 & ,358 & \\
\hline 1 & LTDER &,- 173 & ,082 &,- 367 \\
\hline & SIZE &,- 001 & ,012 &,- 016 \\
\hline
\end{tabular}

Berdasarkan Tabel 3.4, model persamaan regresi yang diperoleh adalah:

$$
\hat{Y}=0,210-0,173 X_{1}-0,001 X_{2}
$$

Dari persamaan regresi di atas, dapat diketahui bahwa struktur modal dan ukuran perusahaan berpengaruh negatif terhadap kinerja keuangan pada Perusahaan Sub Sektor Makanan dan Minuman yang Terdaftar di Bursa Efek Indonesia periode 2015-2017.

\section{2) Koefisien Korelasi dan Determinasi} Tabel 3.5

Koefisien Korelasi dan Koefisien Determinasi

\begin{tabular}{|c|c|c|c|c|}
\hline Model & $\mathrm{R}$ & R Square & $\begin{array}{ll}\begin{array}{l}\text { Adjusted } \\
\text { Square }\end{array} & \mathrm{R} \\
\end{array}$ & $\begin{array}{l}\text { Std. Error of the } \\
\text { Estimate }\end{array}$ \\
\hline 1 &, $371^{\mathrm{a}}$ & ,138 & ,080 & , 104037 \\
\hline
\end{tabular}

Sumber: Hasil Pengolahan Data (SPSS 20), 2018

Dari Tabel 3.5, diperoleh nilai koefisien korelasi ( $r$ ) sebesar 0,371 yang artinya bahwa terdapat hubungan rendah antara variabel struktur modal (LTDER), ukuran perusahaan (SIZE) terhadap variabel dependen kinerja keuangan (ROA). Sementara determinasi (Rsquare) menunjukan angka 0,138, artinya struktur modal dengan proksi (LTDER), ukuran perusahaan ( $S I Z E)$ dapat menjelaskan kinerja keuangan dengan proksi ROA sebesar 13,8\%, sedangkan sisanya $86,2 \%$ dijelaskan oleh variabel lain yang tidak diteliti dalam penelitian ini seperti rasio Return On Equity (ROE), Debt To Asset Ratio (DAR), Basic Earning Power (BEP), Gross Profit Margin (GPM) dan variabel lainya.

3) Uji Hipotesis

(1) Uji Simultan (Uji F)

Hasil uji F dapat dilihat pada Tabel 3.6: Tabel 3.6

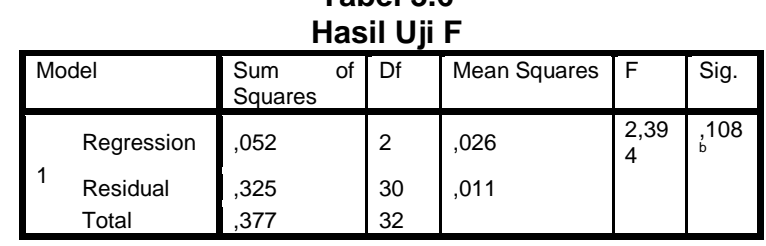

Sumber: hasil Pengolahan Data (SPSS 20), 2018

Dari Tabel 3.6 diperoleh nilai $F_{\text {hitung }}$ sebesar 2,394< $F_{\text {tabel }}(0,05: 2$ VS 30) sebesar 3,32 atau dengan tingkat signifikansi 0,108 $>\alpha$ 0,05 maka $\mathrm{H}_{0}$ diterima, artinya struktur modal dan ukuran perusahaan berpengaruh tidak signifikan terhadap kinerja keuangan pada Perusahaan Sub Sektor Makanan dan Minuman yang Terdaftar di Bursa Efek Indonesia.

(2) Uji Parsial (Uji t)

Hasil uji t dapat dilihat pada Tabel 3.7:

Tabel 3.7

\begin{tabular}{|c|c|c|c|c|c|c|}
\hline \multirow{2}{*}{\multicolumn{2}{|c|}{ Model }} & \multicolumn{2}{|c|}{$\begin{array}{l}\text { Unstandardized } \\
\text { Coefficients }\end{array}$} & \multirow{2}{*}{$\begin{array}{c}\begin{array}{c}\text { Standardize } \\
d \\
\text { Coefficients }\end{array} \\
\text { Beta }\end{array}$} & \multirow[t]{2}{*}{$t$} & \multirow[t]{2}{*}{ Sig. } \\
\hline & & $B$ & Std. Error & & & \\
\hline \multirow{3}{*}{1} & $\begin{array}{l}\text { (Const } \\
\text { ant) }\end{array}$ & 210 & ,358 & & ,587 & ,562 \\
\hline & LTDER & -,173 & 082 &,- 367 & $-2,119$ & ,043 \\
\hline & SIZE & -.001 & .012 & -.016 &,- 093 & .926 \\
\hline
\end{tabular}

Hasil Uji t

Sumber: Hasil Pengolahan Data

Berdasarkan hasil uji t pada Tabel 5.10 dapat diketahui pengaruh masing-masing variabel bebas terhadap variabel terikat yaitu sebagai berikut:

1) $\quad t_{\text {hitung }}>t_{\text {tabel }}(-2,119>1,69726)$ atau Sig. $\leq$ $\alpha 0,05(0,043<0,05)$ maka $\mathrm{H}_{0}$ ditolak, yang berarti bahwa struktur modal berpengaruh negatif signifikan terhadap kinerja keuangan pada Perusahaan Sub Sektor Makanan dan Minuman yang Terdaftar di Bursa Efek Indonesia.

2) $t_{\text {hitung }}<t_{\text {tabel }}(-0,093<1,69726)$ atau Sig. $>$ $\alpha 0,05(0,926>0,05)$ maka $\mathrm{H}_{0}$ diterima, yang berarti bahwa ukuran perusahaan berpengaruh tidak signifikan terhadap kinerja keuangan pada Perusahaan Sub Sektor Makanan dan Minuman yang Terdaftar di Bursa Efek Indonesia.

\subsection{Evaluasi}

3.2.1. Evaluasi Struktur Modal pada Perusahaan Sub Sektor Makanan dan Minuman yang Terdaftar di Bursa Efek Indonesia Periode 2015-2017

Berdasarkan hasil analisis sebelumnya, diketahui bahwa Struktur modal yang diukur dengan Long Term Debt to Equity Ratio (LTDER) cenderung menurun. Hal ini disebabkan oleh jumlah hutang jangka panjang yang rendah dibandingkan total ekuitas.

Untuk itu, jika perusahaan mempunyai hutang yang besar, maka modal perusahaan juga harus besar karena modal yang besar mampu menghasilkan laba yang lebih besar, demikian sebaliknya. Sehubungan dengan itu perusahaan sebaiknya mempertahankan dan meningkatkan stabilitas penjualan, mengelola struktur aset perusahaan, meningkatkan pertumbuhan perusahaan, meningkatkan laba, serta meningkatkan flesibilitas keuangan agar struktur modal perusahaan dapat optimal.

\subsubsection{Evaluasi Ukuran Perusahaan pada}

Perusahaan Sub Sektor Makan dan Minuman yang Terdaftar di Bursa Efek Indonesia Periode 2015-2017

Berdasarkan hasil analisis sebelumnya, diketahui bahwa ukuran perusahaan yang diukur dengan proksi Ln(Total Aset) mengalami peningkatan. Hal ini disebabkan oleh total aset yang meningkat.

Untuk itu, mengoptimalkan ukuran perusahaan maka perusahaan sebaiknya dapat mengolah aset dengan baik untuk dijadikan sebagai sumber pendanaan yang dapat menghasilkan penjualan atau 
pendapatan. Kemampuan perusahaan yang baik dalam mengelolah aset menunjukan kinerja perusahaan yang baik dan hal ini akan dapat menarik perhatian investor untuk ikut mendanai kegiatan perusahaan

\subsubsection{Evaluasi Kinerja Keuangan pada} Perusahaan Sub Sektor Makan dan Minuman yang Terdaftar di Bursa Efek Indonesia Periode 2015-2017

Berdasarkan hasil analisis sebelumnya, diketahui bahwa kinerja keuangan yang diukur dengan proksi Return On Assets (ROA) berfluktuasi dan cenderung meningkat. Hal ini disebabkan terjadinya kenaikan total aset dan laba bersih setelah pajak setiap tahunnya.

Untuk itu, sebaiknya perusahaan menambah jumlah aset supaya volume penjualan meningkat dan diharapkan dapat meningkatkan laba yang besar lagi bagi perusahaan

\subsubsection{Evaluasi Pengaruh Struktur Modal} dan Ukuran Perusahaan Terhadap Kinerja Keuangan pada Perusahaan Sub Sektor Makanan dan Minuman yang Terdaftar di Bursa Efek Indonesia Periode 2015-2017

Berdasarkan pengujian koefisien korelasi dan determinasi dapat diketahui bahwa nilai $r$ adalah 0,371 yang artinya bahwa terdapat hubungan rendah antara variabel struktur modal (LTDER), ukuran perusahaan (SIZE) terhadap variabel dependen kinerja keuangan (ROA). Sementara determinasi (R) menunjukan angka 0,138, artinya struktur modal dengan proksi (LTDER), ukuran perusahaan $(S I Z E)$ dapat menjelaskan kinerja keuangan dengan proksi ROA sebesar 13,8\%, sedangkan sisanya $86,2 \%$ dijelaskan oleh variabel lain yang tidak diteliti dalam penelitian ini seperti rasio Return On Equity (ROE), Debt To Asset Ratio (DAR), Basic Earning Power (BEP), Gross Profit Margin (GPM) dan variabel lainya.

Berdasarkan uji $\mathrm{F}$ diperoleh nilai $F_{\text {hitung }}$ sebesar 2,394 < $F_{\text {tabel }}(0,05: 2$ VS 30) sebesar 3,32 atau dengan tingkat signifikansi 0,108 $>\alpha$ 0,05 maka $\mathrm{H}_{0}$ diterima, artinya struktur modal dan ukuran perusahaan berpengaruh tidak signifikan terhadap kinerja keuangan pada Perusahaan Sub Sektor Makanan dan Minuman yang Terdaftar di Bursa Efek Indonesia. Hal ini tidak sejalan dengan hasil penelitian yang dilakukan Ristania (2017), yang menyatakan bahwa struktur modal berpengaruh signifikan terhadap kinerja perusahaan dan ukuran perusahaan berpengaruh tidak signifikan terhadap kinerja perusahaan.

\section{KESIMPULAN DAN SARAN}

\subsection{Kesimpulan}

1. Struktur modal pada Perusahaan Sub Sektor Makanan dan Minuman yang Terdaftar di Bursa Efek Indonesia tahun
2015-2017 yang diukur dengan rasio Long Term Debt to Equity Ratio (LTDER) cenderung menurun. Hal ini disebabkan oleh jumlah hutang jangka panjang yang rendah dibandingkan total ekuitas.

2. Ukuran perusahaan pada Perusahaan Sub Sektor Makanan dan Minuman yang Terdaftar di Bursa Efek Indonesia tahun 2015-2017 yang diukur dengan rasio SIZE mengalami peningkatan. Hal ini disebabkan, total aset meningkat yang terjadi pada tahun sebelumnya, oleh karena itu perusahaan memiliki kebutuhaan dana yang besar, dan salah satu alternative pemenuhan dana yang tersedia adalah dengan pendanaan aset. Sehingga, dalam rangka pemenuhan pendanaan eksternal tersebut akan lebih meningkatkan kinerja dalam menjalankan perusahaan.

3. Kinerja keuangan pada Perusahaan Sub Sektor Makanan dan Minuman yang Terdaftar di Bursa Efek Indonesia Periode 2015-2017 yang diukur dengan rasio Return On Assets (ROA) cenderung meningkat. Hal ini di sebabkan oleh karena Perusahaan Sub Makanan dan Minuman mengalami peningkatan total aset pada perusahaan. Dengan peningkatan total aset kinerja keuangan menunjukan kemampuan kinerja yang baik bagi perusahaan.

4. Berdasarkan hasil pengujian regresi linier berganda pada penelitian ini bahwa struktur modal dan ukuran perusahaan berpengaruh negatif terhadap kinerja keuangan pada Perusahaan Sub Sektor Makanan dan Minuman yang Terdaftar di Bursa Efek Indonesia periode 2015-2017.

5. Pengujian koefisien korelasi diperoleh hasil, bahwa terdapat hubungan yang rendah antara variabel struktur modal (LTDER), ukuran perusahaan (SIZE) terhadap variabel dependen kinerja keuangan (ROA). Sementara determinasi (r) menunjukan struktur modal dengan proksi (LTDER), ukuran perusahaan $(S I Z E)$ dapat menjelaskan kinerja keuangan tidak terlalu besar, sedangkan sisanya dijelaskan oleh variabel lain yang tidak diteliti dalam penelitian ini seperti rasio Return On Equity (ROE), Debt To Asset Ratio (DAR), Basic Earning Power (BEP), Gross Profit Margin (GPM) dan variabel lainya.

6. Selain simultan, diperoleh bahwa struktur modal dan ukuran perusahaan berpengaruh tidak signifikan terhadap kinerja keuangan pada Perusahaan Sub Sektor Makanan dan Minuman yang Terdaftar di Bursa Efek Indonesia.

7. Berdasarkan hasil pengujian hipotesis dengan uji $\mathrm{t}$ diperoleh bahwa struktur 
modal berpengaruh negatif signifikan sedangkan ukuran perusahaan berpengaruh tidak signifikan terhadap kinerja keuangan pada Perusahaan Sub Sektor Makanan dan Minuman yang Terdaftar di Bursa Efek Indonesia.

4.2. Saran

1. Sebaiknya mempertahankan dan meningkatkan stabilitas penjualan, mengelolah struktur aset perusahaan, meningkatkan pertumbuhan perusahaan, meningkatkan laba, serta meningkatkan flesibilitas keuangan agar struktur modal perusahaan dapat optimal.

2. Sebaiknya dapat mengolah aset untuk dijadikan sebagai sumber pendanaan yang dapat menghasilkan penjualan atau pendapatan. Kemampuan perusahaan yang baik dalam mengelolah aset menunjukan kinerja perusahaan yang baik dan hal ini akan dapat menarik perhatian investor untuk ikut mendanai kegiatan perusahaan.

3. Sebaiknya perusahaan menambah jumlah aset supaya volume penjualan meningkat dan diharapkan dapat meningkatkan laba yang besar lagi bagi perusahaan.

4. Karena berbagai keterbatasan yang dimiliki penulis, maka disarankan untuk peneliti selanjutnya yang ingin meneliti pada Perusahaan Sub Sektor Makanan dan Minuman yang Terdaftar di Bursa Efek Indonesia untuk meneliti kembali penelitian ini, menambah atau mengganti variabel lain di luar variabel dalam penelitian ini serta menambahkan perhitungan untuk meningkatkan kinerja keuangan serta faktor-faktor lain sehingga dapat diketahui pengaruh struktur modal dan ukuran perusahaan terhadap kinerja keuangan pada perusahaan lain dan membuat perbandingannya.

5. DAFTAR PUSTAKA

Astuti, Dewi. 2004. Manajemen Keuangan Perusahaan. Jakarta: Ghalia Indonesia.
Baridwan, Zaki. 2004. Pengantar Akuntansi, Buku 2, Edisi 21. Jakarta. Salemba Empat.

Brigham, Eugene F, dan Joel F. Houston. 2011. Dasar-Dasar Manajemen Keuangan, Buku 1, Edisi 11. Jakarta: Salemba Empat.

Halim, Abdul. 2007. Manajemen Keuangan Bisnis. Jakarta: Ghalia Indonesia.

Hongren, Charles T dan Walter T.Harrison.2007. Akuntansi, Jilid Satu, Edisi Tujuh. Jakarta: Penerbit Erlangga.

Harahap, Sofyan Syafri. 2008. Analisis Kritis Atas Laporan Keuangan. Jakarta. PT Raja Grafindo Persada.

Horne, James C. Van dan John. Wachowicz. 2013. Prinsip-Prinsip Manajemen Keuangan, Edisi Ketga. Buku Pertama. Jakarta: Salemba Empat.

Munawir, Slamet. 2010. Akuntansi Keuangan dan Manajemen, Edisi Revisi. Yogyakarta : Liberty.

2014. Analisis Laporan Keuangan. Yogyakarta: Liberty.

Martani, Dwi, Dkk. 2012. Akuntansi Keuangan Menengah Berbasis PSAK, Buku I. Jakarta : Salemba Empat.

Rudianto. 2009. Pengantar Akuntansi. Jakarta: Erlangga.

2013. Pengantar Akuntansi. Jakarta: Erlangga.

Riyanto, Bambang. 2009. Dasar-Dasar Pembelanjaan Perusahaan. Yogyakarta: BPFE Yogyakarta.

Sawir, Agnes. 2004. Kebijakan Pendanaan dan Restrukturisasi Perusahaan. Jakarta: PT. Gramedia Pustaa Utama.

Sartono, Agus. 2010. Manajemen Keuangan dan Aplikasi. Yogyakarta : BBFE.

Subramanyam, dan Wilid John.2010. Analisis Laporan Keuangan, Buku 1. Jakarta. Erlangga.

Sudana. 2011. Manajemen Keuangan Perusahaan. Teori dan Praktek. Jakarta. Erlangga. 